\begin{tabular}{|c|c|c|}
\hline 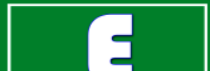 & International Journal of Current Research in & \\
\hline & Biosciences and Plant Biology & \\
\hline $\begin{array}{l}\text { EX } \\
\text { PUBL }\end{array}$ & $\begin{array}{c}\text { ISSN: 2349-8080 (Online) • Volume } 3 \bullet \text { Number } 3 \text { (March-2016) } \\
\text { Journal homepage: www.ijcrbp.com }\end{array}$ & \\
\hline
\end{tabular}

Original Research Article

doi: http://dx.doi.org/10.20546/ijcrbp.2016.303.010

\title{
Pharmacognostic Studies and Phytochemical Screening of Pterospermum acerifolium Leaves
}

\author{
Mathew George*, Lincy Joseph, Neetu Deshwal and Jeenu Joseph \\ Pushpagiri College of Pharmacy, Medicity Campus, Perumthuruthy P.O, Thiruvalla, Kerala 689 107, India \\ *Corresponding author.
}

\section{Abstract}

Pterospermum acerifolium (Sterculiaceae family) is traditionally used for ear pain, Small pox, leucorrhoea, inflammation, ulcers, leprosy, blood disorders, tumours, diabetics. In present investigation, the detailed pharmacognostic study of leaf of Pterospermum acerifolium is carried out to lay down the standards which could be useful in future experimental studies. The study includes macroscopy, microscopy, preliminary phytochemical screening and physicochemical evaluation.

\section{Article Info}

Accepted: 16 February 2016

Available Online: 06 March 2016

\section{Ke ywords}

Pharmacognosy

Phytochemicals

Pterospermum acerifolium

\section{Introduction}

It is not unreasonable to believe that the plant kingdom should yield safe and effective drugs for most of the human ailments .Though India has a rich tradition in the use of medicinal plants, the effort to develop drugs from plants has had limited success. Hence, plants have returned to the fore front in drug development as medicines, as source of active molecules and as lead to the discovery of new drugs. The use of medicinal plants to treat various diseases in India dates back to the times of Rig-Veda (3500-1800BC). Later, the monumental Ayurveda works like charaksamhita and sushurtsamhita followed by other Ayurveda drugs entering in to several medicinal preparations were in the management of health care. In fact these systems have been in practice even in remote areas of our country for centuries. World Health Organization (WHO) estimates that $80 \%$ of the people living in developing countries almost exclusively using traditional medicine and about 119 secondary metabolites of plants are used globally as drugs (Kumar et al., 2006)
Herbal drugs constitute only those traditional medicines, which primarily use medicinal plants preparation for therapy. The earliest recorded evidence of their use in in Indian, Chinese, Egyption, Greek, Roman and Syrian text dates back to about 5000 years. The classical Indian texts include Rigveda, Atharvaveda, CharakSamhita and SushrutaSamhita. The herbal medicines/traditions of ancient civilization and scientific heritage (Kamboj, 2000)

Pterospermum acerifolium (Sterculiaceae family) is well distributed in India, particularly in sub-Himalayan tract and outer Himalayan valleys. Common name is kanakchampa or muchukunda. Externally the leaves are variable in shape and size, $25-35 \mathrm{~cm} \mathrm{(1),} 15-30 \mathrm{~cm} \mathrm{(w),} \mathrm{orbicular} \mathrm{or} \mathrm{oblong,}$ entire or various lobed, cordate, glabrous above and clothed beneath with whitish floccose tomentum (Kirtikar, 1996). Flavonoids in the leaves include luteolin-7-O- $\beta$-D glucuronode, luteolin-7-O- $\beta$-D glucoside, kaempferol-3-O$\beta$-D galactoside, friedeline, barurenol (Gunase, 1979). Traditionally it is used for ear pain, Small pox, leucorrhoea, inflammation, ulcers, leprosy, blood disorders, tumours, diabetics (Chandra, 2005). 


\section{Materials and methods}

\section{Collection of plant material}

Fresh leaves of Pterospermum acerifolium (Sterculiaceae family) collected in the month of August 2010 from Bhopal, dried under shade and powdered in a mixer grinder. The powdered leaves were packed in air bags and stored in air tight containers until use.

\section{Authetification}

The botanical identity was confirmed by department of Botany, Safia College of Science, Bhopal (M.P) where voucher specimen number (148/BOT/SAFIA/2010) has been deposited for further references.

\section{Pharmacognostic evaluation}

Stomatal number: It is the average number of stomata per square $\mathrm{mm}$ of the epidermis of leaf which has been counted microscopically.

Stomatal index: It is the percentage which the number of stomata forms to the total number of cells, each stomata being counted as one cell. Stomatal Index can be calculated by equation:

$$
\mathrm{I}=\mathrm{S} / \mathrm{E}+\mathrm{S} \times 100
$$

Where, I= Stomatal Index; $S=$ No. of stomata per unit area; E= No. of epidermal cells in the same unit area.

Palisade ratio: It is the average no: of palisade cells beneath one epidermal cells of a leaf. It is determined by counting the palisade calls beneath four continuous epidermal cells.

Vein-islet: It is the average number of vein per square millimeter. It is determined by counting number of Veinislet in the area of 4 sq.mm of the central part of leaf between midrib and margin

Vein-islet number: It is defined as number of vein termination per square millimeter of leaf surface, midway between midrib and margin (Khandelwal, 2005).

\section{Results}

Phytochemical screening: The preliminary phytochemical screening was done by standard qualitative chemical tests for the hydroalcoholic leaf extract and chloroform extract and showed the presence of tannins, phenolics and flavonoids (Table 1). The evaluation and standardization parameters of the leaves of Pterospermum acerifolium are given in Tables 2 and 3 . The observations on the transverse section of leaf of Pterospermum acerifolium, collenchyma, trichomes and mucilage cells are given in Figs. 1-5.

Table 1. Phytochemical screening of Pterospermum acerifolium.

\begin{tabular}{|c|c|c|}
\hline Constituents & $\begin{array}{l}\text { Chloroform } \\
\text { extract }\end{array}$ & $\begin{array}{l}\text { Hydroalcoholic } \\
\text { leaf extract }\end{array}$ \\
\hline Alkaloids & - & - \\
\hline Carbohydrates & - & - \\
\hline Tannins and phenolics & + & + \\
\hline Glycosides & - & - \\
\hline Flavonoids & + & + \\
\hline Saponins & - & - \\
\hline Steroids & - & - \\
\hline \multicolumn{3}{|c|}{$\begin{array}{l}\text { - Indicate absence of chemical constituents; }+ \text { Indicate } \\
\text { presence of chemical constituents. }\end{array}$} \\
\hline \multicolumn{3}{|c|}{$\begin{array}{l}\text { Table 2. Evaluation parameters of leaf of Pterospermun } \\
\text { acerifolium. }\end{array}$} \\
\hline \multicolumn{2}{|c|}{ Evaluation parameter } & Range \\
\hline \multicolumn{2}{|c|}{ Stomatal number (upper peel) } & $15-17$ \\
\hline \multicolumn{2}{|c|}{ Stomatal Index } & $25.2-26.6$ \\
\hline \multicolumn{2}{|c|}{ Palisade ratio } & $1: 6$ \\
\hline \multicolumn{2}{|c|}{ Vein islet number } & $28-30$ \\
\hline \multicolumn{2}{|c|}{ Vein termination number } & $60-65$ \\
\hline
\end{tabular}

Table 3. Standardisation parameters of leaf of Pterospermum acerifolium.

\begin{tabular}{lll}
\hline Sl. No. & Evaluation parameter & Value \\
\hline 1. & Moisture content & 8.44 \\
2. & Total ash & 4.67 \\
3. & Acid insoluble ash & 0.33 \\
4. & Water soluble ash & 2.67 \\
5. & Crude fibre analysis & 18 \\
6. & Water soluble extractive & 3.25 \\
7. & Alcohol soluble extractive & 5.75 \\
\hline
\end{tabular}

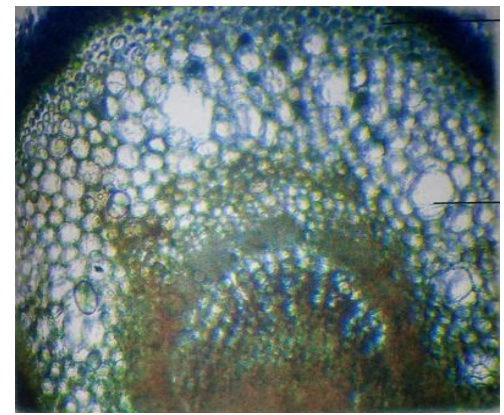

Fig. 1: Transverse section of the leaf. 


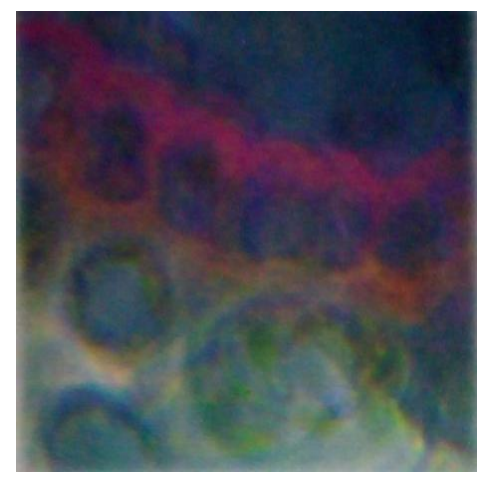

Fig. 2: Collenchyma.

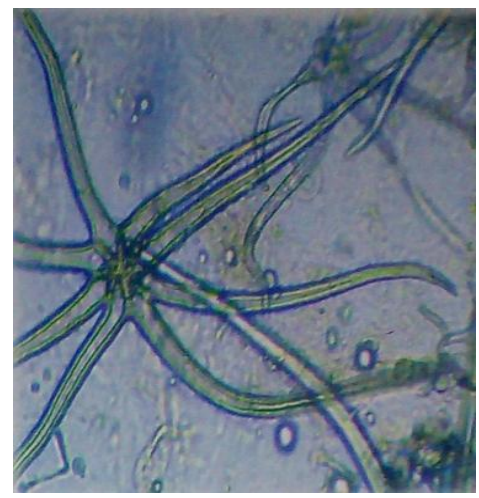

Fig. 3: Covering trichomes.

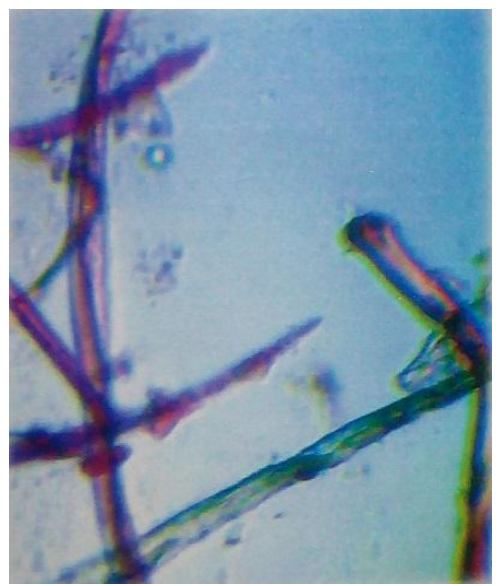

Fig. 4: Lignified trichomes.

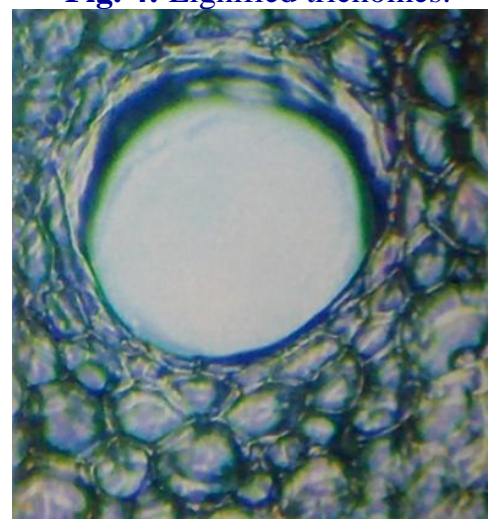

Fig. 5: Mucilage cells.
Organoleptic studies: The results obtained for the organoleptic studies for Pterospermum acerifolium is given hereunder.

$\begin{array}{lll}\text { Colour } & - & \text { Green } \\ \text { Odour } & - & \text { Characteristic } \\ \text { Taste } & - & \text { Bitter } \\ \text { Surface } & - & \text { Rough }\end{array}$

Macromorphology: The results obtained for macromorphological features of Pterospermum acerifolium is given below.

Colour - Upper surface-dark green, glabrous

Lower surface- silvery to rusty pubescent

Size

Lamina $\quad-25-35 \mathrm{~cm}$ (1) $15-30 \mathrm{~cm} \mathrm{(b)}$

Petiole $\quad-\quad 5-15 \mathrm{~cm} \mathrm{(l)}$

Margin - wavy to distantly coarse toothed or irregularly lobed

Venation - pinnate reticulate

Incision - palmatifid

Apex - acuminate

Base - asymmetrical

\section{Transverse section of different parts of Pterospermum acerifolium}

Midrib:

Epidermis - single layer covered with cuticle

Hypodermis - contain 6-7 layers of collenchyma

Cortex - several mucilaginous glands in parenchyma

Vascular bundle - conjoint, collateral

Pith - large with oil canals. Vascular bundle scatters in pith

Trichomes: Three types of trichomes were observed in Pterospermum acerifolium.

1. Unicellular long simple trichomes

2. Stellate with long arms

3. Glandular trichomes

\section{Lamina:}

Upper epidermis - Thick walled polygonal cells, stomata absent.

Lower epidermis - Thin walled cell with anomocytic stomata and glandular trichomes.

Mesophyll - Not clearly differentiated between spongy tissue and palisade cells. 2-3 layers of palisade cells below the upper epidermis. 


\section{Conclusion}

The results of the study can serve as a valuable source of information and provide suitable standards for identification of Pterospermum acerifolium (Sterculiaceae family) in future investigations and applications.

\section{Conflict of interest statement}

Authors declare that they have no conflict of interest.

\section{References}

Chandra, P. K., 2005. Ethnomedicinal botany of the Apatani in the Eastern Himalayan regions of India. J. Ethnobiol. Ethnomed. 1(11), 1-8.
Gunase, G.R., Subramaniam, S.S., 1979. Flavonoids of three Ptrerospermum. Indian J. Pharm. Sci. 78, 72-73.

Kamboj, V.P., 2000. Herbal medicines. Curr. Sci.78(1), 35-44.

Khandelwal, K.R., 2005, Practical Pharmacognosy. Nirali Prakashan, Pune. pp.149-153.

Kirtikar, K.R., Basu, B.D., 1994. Indian Medicinal Plants Periodical Book. New Delhi. 371p.

Kumar, M.S., Sripriya, R., Vijaya, R.H., Sehgal, P.K., 2006. Wound healing potential of Cassia fistula on infected albino rat model. J. Surgical Res. 131, 283-89.

WHO, 1998. World Health Organization, Quality Control Methods of Medicinal Plant Materials, Switzerland.

\section{How to cite this article:}

George, M., Joseph, L., Deshwal, N., Joseph, J., 2016. Pharmacognostic studies and phytochemical screening of Pterospermum acerifolium leaves. Int. J. Curr. Res. Biosci. Plant Biol. 3(3), 53-55. doi: http://dx.doi.org/10.20546/ijcrbp.2016.303.010 